\title{
Kelompok Pendamping Kehamilan Risiko Tinggi (Kp-Krt) Berbasis Continuity Of Care
}

\author{
Sri Wahyuni ${ }^{1}$, Tutik Rahayu ${ }^{2}$, Hernandia Distinarista ${ }^{3}$ \\ Fakultas IImu Keperawatan Universitas Islam Sultan Agung \\ Email: wahyuni@unissula.ac.id
}

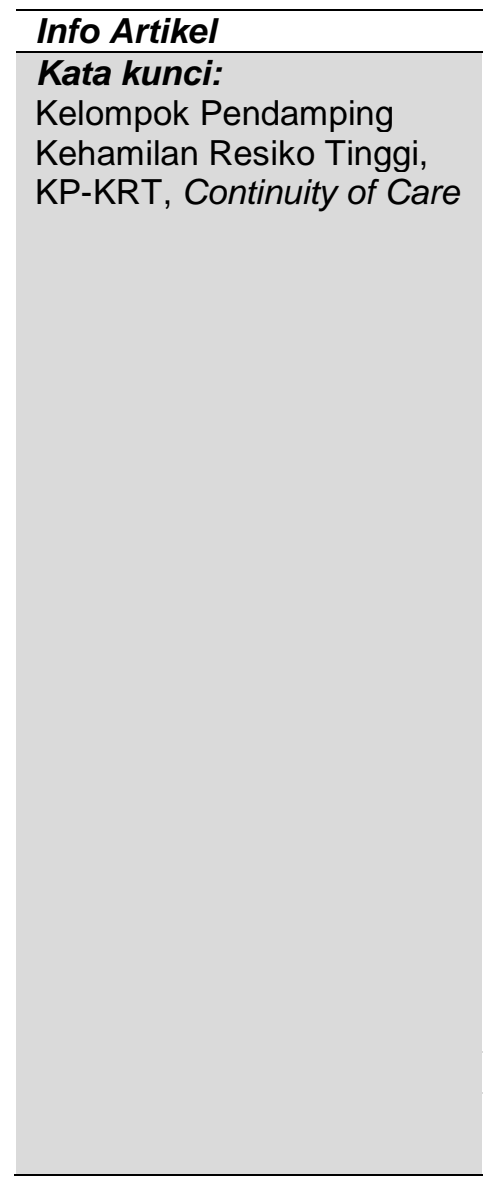

\begin{abstract}
Abstrak
Kehamilan merupakan bagian dari proses maturasi perempuan yang memiliki berbagai risiko kesehatan. Kehamilan risiko tinggi menjadi faktor utama peningkatan AKI dan AKB di Indonesia. Kelurahan Bandarharjo Semarang Utara terdapat mempunyai warga dengan kondisi hamil risiko tinggi. Ibu memeriksakan kehamilannya di Puskesmas, namun pelayana yang diberikan masih sebatas Antenatal Care yang dilakukan rutin setiap bulannya. Karakteristik keluarga ibu hamil juga tidak memahami cara perawatan sehingga diperlukan upaya untuk mengatasi masalah tersebut dengan program pendampingan yang dilakukan secara berkesinambungan. Program tersebut berupa Kelompok Pendamping Kehamilan Resiko Tinggi (KP-KRT) berbasis continuity of care untuk menurunkan resiko -resiko yang terjadi pada Ibu hamil. Methode pada Program Kemitraan Masyarakat (PKM) ini dilaksanakan dalam 4 tahap yaitu yaitu (1) Sosialisasi, (2) Peningkatan kompetensi, (3) Latihan ketrampilan atau pelaksanaan kegiatan, dan (4 ) Monitoring dan Evaluasi. Hasil dari pelaksanaan PKM dapat teridentifikasi ibu hamil yang mengalami resiko tinggi, didirikannya rumah kehamilan sejahtera, meningkatkan kompetensi kader melalui pelatihan, dan terbentuknya alur rujukan ibu hamil resiko tinggi. Kesimpulan, pentingnya pendampingan pada ibu hamil untuk menurunkan resiko yang terjadi pada kehamilan. Saran, diperlukannya pemantauan dan follow up dari pemerintah khususnya puskesmas setempat untuk menjaga keberlangsungan dari program KP-KRT.
\end{abstract}

\section{PENDAHULUAN}

Kehamilan merupakan bagian dari proses maturasi seorang perempuan yang memiliki berbagai risiko kesehatan, bahkan mengancam nyawa pada ibu dan bayinya. Pada tahun 2010, sekitar 287.000 kematian ibu terjadi di seluruh dunia dan meningkat menjadi 303.000 kematian ibu pada tahun 2015. Meskipun berbagai upaya intervensi berbasis bukti telah dilakukan untuk menekan kematian ibu, namun sekitar 800 perempuan terus meninggal setiap hari akibat komplikasi kehamilan dan persalinan, serta sekitar 99\% (302.000) dari kematian ini terjadi di negara berkembang (Ross, Ren, Land, Chandrasekaran, \& Mintz, 1990). Angka kematian neonatal juga tinggi, meskipun ketersediaan intervensi berbasis bukti dapat mencegah hingga $72 \%$ dari kematian neonatal (Lefevre et al., 2013).

Jumlah angka kematian ibu (AKI) di Indonesia pada tahun 2013 adalah 359/100.000 kelahiran hidup. AKI di Jawa Tengah mencapai 711 kasus pada tahun 2014. Angka tersebut lebih tinggi dibanding kejadian antara tahun 2010 dan 2013 secara berurutan, yaitu 611 (2010), 668 (2011), 675 (2012), dan 668 (2013) (KEMENKES, 2018). Sebagian besar ibu lebih banyak melakukan kontrol pada tahap kehamilannya saja atau bahkan tidak melakukan kontrol kesehatan sama sekali kecuali jika ada komplikasi yang dialami. Padahal berdasarkan riset diketahui bahwa antenatal care yang rutin dapat meningkatkan status kesehatan ibu hamil (Patel et al., 2016).

Bandarharjo merupakan salah satu kelurahan yang terletak di wilayah Semarang utara dengan luas wilayah $342.675 \mathrm{Ha}$ dan ketinggian \pm 2 mdpl. Kelurahan Bandarharjo memiliki 12 RW 
dan 103 RT. Wilayah ini mempunyai iklim tropis dan memiliki dua musim yaitu musim penghujan dan musim kemarau seperti daerah-daerah di Indonesia pada umumnya dengan suhu udara rata-rata \pm $23^{\circ} \mathrm{C}$.

Kelurahan Bandarharjo memiliki jumlah penduduk sebanyak $4.319 \mathrm{KK}$ yang terdiri dari penduduk laki-laki sejumlah 10,294 jiwa dan penduduk perempuan sejumlah 10,149 jiwa dengan total penduduk 20.443 jiwa. Berdasarkan jumlah penduduk tersebut, saat ini terdapat ibu hamil risiko tinggi sebanyak 67 orang yang perlu mendapatkan pendampingan terhadap kondisi kesehatannya.

Upaya yang dilakukan oleh pemerintah dalam hal ini Puskesmas Bandarharjo pada Ibu hamil adalah melalui pemeriksaan rutin ANC ke Puskesmas. Belum ada tindakan khusus yang dilakukan untuk ibu hamil resiko tinggi.

Hasil survei menunjukkan bahwa sebagian besar ibu hamil memiliki masalah seperti kehamilan dengan hipertensi, kehamilan dengan KEK, hamil dengan usia diatas 35 tahun, hamil dengan usia kurang dari 20 tahun dan jarak kehamilan yang terlalu dekat. Ibu hamil tersebut tidak melakukan pemeriksaan kehamilan secara rutin karena harus bekerja untuk memenuhi kebutuhan sehari-harinya sementara anggota keluarganya tidak memiliki pengetahuan dan kemampuan yang cukup memadai untuk merawat keluarga dengan kehamilan risiko tinggi dan mencegah berbagai faktor risiko yang terjadi. Hal ini dapat menyebabkan diagnosis gangguan kehamilan terdeteksi secara lambat dan dapat mengancam keselamatan ibu dan janin.

Kondisi yang dialami oleh ibu hamil di wilayah kelurahan Bandarharjo perlu dilakukan penanganan secara baik dan berkesinambungan. Upaya dapat dilakukan melalui pendekatan identifikasi terhadap risiko dan persiapan pengetahuan pada ibu hamil sangat penting untuk meningkatkan kesejahteraan ibu dan janin. Penggunaan pelayanan antenatal yang tidak proporsional sesuai dengan tingkat risiko kehamilan menunjukkan perlunya pendekatan yang lebih baik pada ibu hamil untuk meningkatkan fasilitas pelayanan kesehatan. Diperlukannya kerjasama yang baik dari pemberi pelayanan kesehatan (Yeoh, Hornetz, \& Dahlui, 2016).

Upaya akan berkesinambungan ketika optimalisasi sumberdaya masarakat dapat dilibatkan dengan menggunakan konsep pelayanan berbasis Continuity of $\mathrm{Care}(\mathrm{CoC})$. Pelayanan berbasis $\mathrm{COC}$ ini merupakan pendekatan proses keperawatan yang berfokus pada pemenuhan kebutuhan ibu-bayi secara bersama-sama sebagai satu unit dengan mempertimbangkan keterlibatan keluarga, pemberian privasi, menciptakan lingkungan bersih, hangat, dan ramah serta dibutuhkan adanya pendampingan dalam pemberian perawatan yang memenuhi atau menyesuaikan dengan kebutuhan fisik, psikologis, dan spiritual ibu, bayi, serta keluarga. Hal ini dilakukan untuk menurunkan resiko yang terjadi pada periode ante natal, intra natal dan post natal serta untuk meningkatkan kepuasan pelayanan (Forster et al., 2016).

Beberapa pertimbangan untuk memilih program KP-KRT berbasis CoC sebagai upaya promotif dan preventif untuk meningkatkan kesejahteraan ibu dan janin berdasarkan penelitian yang telah dipublikasikasn. Hasil penelitian menunjukkan bahwa CoC dapat mengurangi penggunaan intervensi medis obstetrik selama persalinan dan menurunkan angka kematian ibu dan anak (Sandall, Soltani, Gates, Shennan, \& Devane, 2016).

Kelurahan Bandarharjo Semarang utara memiliki potensi yang sangat baik untuk keberlangsungan program ini, dengan melibatkan kader dalam pendampingan ibu hamil resiko tinggi. Kader kesehatan di kelurahan semuanya aktif dalam tiap kegiatan yang diselanggarakan kelurahan sehingga dengan mudah untuk menjalankan program kelompok pendampingan pada keluarga dengan kehamilan risiko tinggi (KP-KRT).

\section{BAHAN DAN METODE}

Metode pelaksanaan dalam Program Kemitraan Masyarakat ini dilaksanakan dalam 4 (empat) tahapan, Tahap Pertama Sosialisasi. Pada tahapan ini dilakukan Sosialisasi mengenai program PKM dan alur serta tahapan program PKM. Tahapa kedua adalah Peningkatan kompetensi. Pada Tahap kedua ini dilakukan curah pendapat tentang kehamilan dan permasalahan yang dihadapi di masyarakat serta peningkatan kompetensi dari Kader Pendamping Kehamilan Resiko Tinggi melalui pelatihan kader. Pada Tahap kedua ini juga dibentuk Rumah Kehamilan Sejahtera sebagai sarana untuk mewadahi aktifitas Kelompok Kader Pendamping Kehamilan Resiko Tinggi. Tahapan yang ketiga adalah Latihan ketrampilan atau pelaksanaan kegiatan. Pada tahap ketiga kader dilatih untuk melakukan identifikasi dan pengkajian status ibu hamil untuk mengklasifikasikan apakah kondisi kehamilan yang dialami ibu termasuk dalam kehamilan beresiko. Tahap ini juga dilakukan kerjasama 
dengan Puskesmas dan kader diberikan pelatihan untuk melakukan cara pelaporan pada Puskesmas. Tahap Keempat adalah Monitoring dan Evaluasi. Pada tahap ini dilakukan monitoring dan evaluasi terhadap kegiatan yang dilaksanakan oleh kader pendampingan kehamilan risiko tinggi.

\section{HASIL DAN DISKUSI}

\section{Identifikasi Kader Kesehatan}

Pelaksanaan PKM Kelompok Pendamping Kehamilan Resiko Tinggi (KP-KRT) di wilayah Kelurahan Bandarharjo Semarang utara ini dapatkan kader yang tergabung dalam KP-KRT sejumlah 13 Orang. Kader mewakili dari seluruh wilayah di Kelurahan Bandarharjo yang terdiri dari 12 RW dan 1 kader merupakan ketua penggerak PKK.

Kader yang telah diidentifikasi dikumpulkan untuk diberikan informed Consent dalam keterlibatannya pada kegiatan yang diselenggarakan. Informed Consent ini perlu diberikan untuk memberikan kejelasan pada kader tentang kegiatan yang akan dilakukan, prosedur, manfaat serta kemungkinan resiko yang akan terjadi pada kegiatan yang dilakukan. Keterlibatan subjek dalam aktifitas, termasuk dalam halini kader perlu mendapatkan informasi yang jelas dan kepesertaannya harus atas dasar sukarela (Purcaru, Preda, Popa, Moga, \& Rogozea, 2014). Hasil dari informed consent, 13 kader yang mewakili masing-masing RW 100\% setuju untuk menjadi kader pendamping kehamilan resiko tinggi.

Komitmen dengan kader dilaksanakan setelah informed consent diberikan. Kominten perlu dilakukan untuk menyelaraskan pola fikir dan mengikat seseorang ke suatu program tindakan dengan target tertentu (Vandenberghe, Bentein, \& Stinglhamber, 2004). Dalam hal ini komitmen dilakukan pada kader pendamping kehamilan resiko tinggi. Pada pelaksanaan kegiatan diperoleh bahwa seluruh kader100\% KP-KRT seluruhnya mengikuti kegiatan dari awal sampai dengan monitoring evaluasi. Seluruh kader KP-KRT kooperatif dan bekerjasama dengan baik untuk melakukan kegiatan dan mencapai target yang telah ditentukan.

\section{Pelatihan Kader}

Kegiatan yang dilaksanakan untuk meningkatkan kompetensi KP-KRT adalah dengan memberikan pelatihan kader. Adapun materi yang diberikan pada pelatihan kader meliputi: Konsep kehamilan Normal, Kehamilan Kehamilan Resiko Tinggi dan Upaya Upaya Deteksi dini, Kehamilan Resiko Tinggi dan Upaya Perawatannya, Manajemen laktasi, Pemanfaatan Fasilitas Kesehatan, Manajemen Stress Pada Kehamilan Resiko Tinggi dan monitoring kesejahteraan janin, Latihan fisik pada kehamilan risiko tinggi dan Pengaturan Jarak Kehamilan melalui Kontrasepsi.

Sebelum dilakukan pelatihan kader diadakan Pre Test terhadap kemampuan yang dimiliki oleh kader dan setelahnya dilakukan Post test. Adapun hasilnya sebagai berikit:

Tabel 1.1. Gambaran Pengetahuan Kader Kelompok Pendamping Kehamilan Resiko Tinggi Kelurahan Bandarharjo Semarang Utara Tahun 2019 ( $n=13)$

\begin{tabular}{|l|l|l|l|l|}
\hline Tingkat Pengetahuan & \multicolumn{2}{l|l|}{ Pre Test } & \multicolumn{2}{l|}{ Post Test } \\
\hline & $\mathbf{n}$ & \% & $\mathbf{n}$ & $\%$ \\
\hline Rendah & 1 & 7,6 & 0 & 0 \\
\hline Sedang & 8 & 61,7 & 0 & 0 \\
\hline Tinggi & 4 & 30,7 & 13 & 100 \\
\hline Total & 13 & 100 & 13 & 100 \\
\hline
\end{tabular}

Tabel menunjukkan bahwa sebelum dilakukan pelatihan sebagian besar kader kader yang mempunyai tingkat pengetahuan sedang juga terdapat $7,6 \%$ kader yang masih rendah pengetahuannya tentang kehamilan resiko tinggi. Setelah dilakukan pelatihan selama 2 hari pengetahuan kader meningkat dengan hasil post test $100 \%$ kader mempunyai tingkat pengetahuan yang tinggi. 
Pelatihan merupakan upaya untuk meningkatkan pengetahuan, dengan di berikan pelatihan subjek dalam hal ini kader akan terpapar tentang materi-materi pembelajaran dengan berbagai macam topik baru yang mampu menambah wawasan (Fatumo, Shome, \& Macintyre, 2014). Terlebih kader pada saat pelatihan dilakukan dengan berbagai macam method diantaranya adalah, ceramah, pemutaran video dan demonstrasi atau praktikum. Sebagaimana penelitian yang dilakukan oleh (KORKMAZ TOKLUCU \& TAY, 2016) menyebutkan bahwa pemberian materi yang dilakukan secara inovatif akan meningkatkan pemahaman dan pemahaman akan bertahan lama (retensi).

Pembentukan Rumah Kehamilan Sejahtera

Untuk kelancaran dan keberlangsungan kegiatan dibentuk Rumah Kehamilan Sejahtera. Rumah ini didirikan dengan tujuan sebagai wadah kegiatan kader pendamping di wilayah kelurahan. Rumah kehamilan sejahtera dilengkapi dengan fasilitas sarana prasarana meliputi, papan nama, lemari , timbangan berat badan, mitline (meteran), pengukur LILA, tensi meter digital, thermometer digital, jam dinding, kipas angina, kabel rol, leaflet, buku pemantauan kehamilan dan kartu pemantauan ibu hamil.

Posko atau sentral kegiatan untuk berkumpulnya tim menjadi suatu kebutuhan yang penting. Dengan adanya posko maka kader akan mampu belajar secara berkelompok dan saling memotivasi untuk melakukan kegiatan. Saling membantu untuk meningkatkan kelancaran kemampuan dan kinerja ("The Effect of Communicative Activities on EFL Learners 'Motivation: A Case of Students in the Amazon Region of Ecuador Efecto de actividades comunicativas en la motivación de aprendices del inglés : un caso de estudiantes en la región amazónica del Ecua," 2016)

\section{Identifikasi Ibu Hamil di Kelurahan Bandarharjo}

Kader kesehatan yang telah diberikan pelatihan melakukan identifikasi data ibu hamil. Kader melakukan screening terhadap ibu hamil yang ada di wilayah Kelurahan Bandarharjo. Dari hasil identifikasi dan screening diperoleh data sebagai berikut:

Tabel 2.1. Identifikasi data ibu hamil di wilayah Kelurahan Bandarharjo Semarang Utara

\begin{tabular}{|l|l|l|}
\hline Identifikasi Ibu Hamil & Jumlah & Prosentase \\
\hline Usia Kehamilan & & \\
\hline Trimester I & 23 & $31,6 \%$ \\
\hline Trimester II & 32 & $43,8 \%$ \\
\hline Trimester III & 18 & $24,6 \%$ \\
\hline Keluhan/ Kondisi & & \\
\hline Hipertensi & 11 & $15 \%$ \\
\hline Keluhan Nyeri Punggung & 17 & $23,3 \%$ \\
& & \\
\hline Ringan & 2 & $11,7 \%$ \\
\hline Sedang & 9 & $52,9 \%$ \\
\hline Berat & 6 & $35,3 \%$ \\
\hline Gemeli & 1 & $1,3 \%$ \\
\hline Bekas Sc & 7 & $9,5 \%$ \\
\hline Usia $\leq 20$ Tahun & 5 & $6,8 \%$ \\
\hline Usia $\geq 35$ Tahun & 2 & $2,7 \%$ \\
\hline
\end{tabular}

Jumlah seluruh ibu hamil yang ada di kelurahan Bandarharjo sebanyak 73 dengansebagian besar ibu hamil berada pada utia kehamilan Trimester kedua. Terdapat $11 \mathrm{lbu}$ hamil yang mengalami hipertensi dalam kehamilan, dan sebanyak 17 Orang lbu hamil mengalami keluhan Nyeri punggung. Dari hasil identifikasi juga diketahui terdapat 7 orang ibu hamil yang bekas operasi section caesaria.

Hasil identifikasi sangat penting untuk menentukan status kesehatan ibu, yang dapat digunakan untuk tindakan penanganan pada ibu agar tidak menimbulkan komplikasi pada kehamilan. Screening atau deteksi dini yang dilakukan sejak awal dapat bermanfaat untuk melakukan deteksi secara awal pada kondisi prenatal (S.Y. et al., 2018). 


\section{Teknis Rujukan dan Kerjasama dengan Puskesmas}

Kegiatan PKM KP-KRT akan dapat berlangsung dengan bekerjasama pada instansi terkait. Dalam Hal ini Dinas Kesehatan, dimana kelurahan Bandarharjo berada dibawah wilayah Puskesmas Bandarharjo. Kegiatan mendapatkan support dan dukungan maksimal dari Kepala Puskesmas Bandarharjo dan Kepala Kelurahan Bandarharjo. Diperolehnya kesepakatan model jenjang rujukan dan pelaporan ibu hamil serta pengelolaan continuity of care dengan alur sebagai berikut:

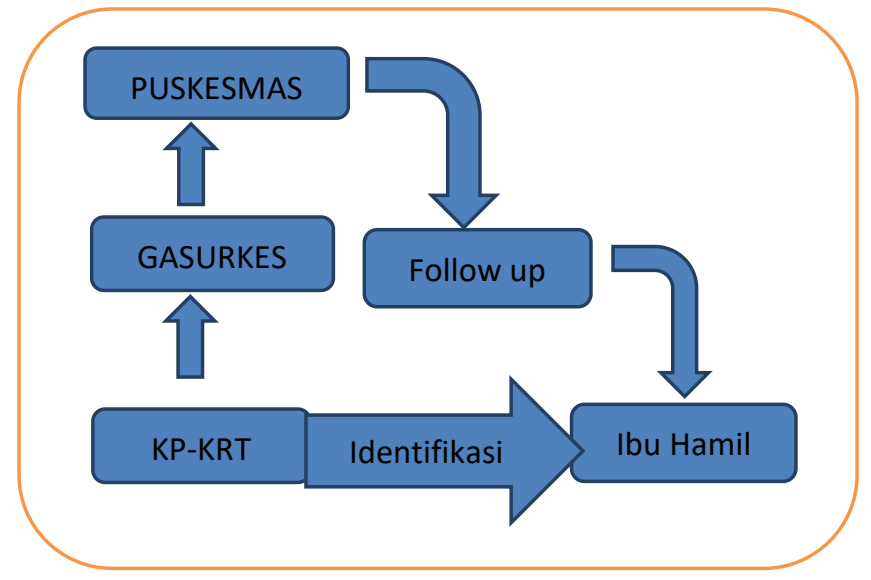

Gambar 1.1. Alur KP-KRT berbasis Continuity of Care

gambar diketahui bahwa, pengelolaan ibu hamil resiko tinggi oleh KP-KRT berbasis Continuity of Care di wilayah kelurahan Bandarharjo dimulai dari identifikasi ibu hamil oleh KP-KRT, selanjutnya KP-KRT melaporkan hasil pada petugas surveilans kesehatan (Gasurkes) yang selanjutnya Gasurkes meneruskan laporan ke Puskesmas. Hasil Laporan dilakukan follow up oleh Puskesmas.

Alur pelaporan harus jelas dan disepakati oleh instansi yang menjadi rujukan, mengingat ibu hamil wilayah kerja Puskesmas. Alur rujukan sangat penting untuk disepakati dan ditaati untuk kemudian dilaksanakan dengan cermat, kegagalan dalam melaksanakan rujukan yang tepat akan berdampak pada keterlambatan dalam penyediaan perawatan (Singh, Doyle, Campbell, Mathew, \& Murthy, 2016).

\section{UCAPAN TERIMAKASIH}

Terimakasih banyak kami ucapkan Terimakasih Kepada Direktorat Riset dan Pengabdian Kepada Masyarakat Kemenristek Dikti Atas Dana Hibah Program Kemitraan Masyarakat Tahun 2019. Terimakasih juga kepada Pimpinan Unissula, LPPM Unissula dan Pimpinan Fakultas IImu Keperawatan, Kepala Puskesmas Bandarharjo, Kepala Kelurahan dan Kader Kesehatan yang telah memberikan dukungan maksimal.

\section{REFERENCES}

Fatumo, S., Shome, S., \& Macintyre, G. (2014). Workshops: A Great Way to Enhance and Supplement a Degree. PLoS Computational Biology, 10(2), 1-3. https://doi.org/10.1371/journal.pcbi.1003497

Forster, D. A., McLachlan, H. L., Davey, M. A., Biro, M. A., Farrell, T., Gold, L., ... Waldenström, U. (2016). Continuity of care by a primary midwife (caseload midwifery) increases women's satisfaction with antenatal, intrapartum and postpartum care: Results from the COSMOS randomised controlled trial. BMC Pregnancy and Childbirth, 16(1), 1-13. https://doi.org/10.1186/s12884-016-0798-y

KEMENKES. (2018). Hasil Utama Riskesdas Tentang Prevalensi Diabetes Mellitus di Indonesia 2018. Hasil Utama Riskesdas Tentang Prevalensi Diabetes Melitus Di Indonesia 2018, 8.

KORKMAZ TOKLUCU, S., \& TAY, B. (2016). The Effect of Cooperative Learning Method and 
Systematic Teaching on Students' Achievement and Retention of Knowledge in Social Studies Lesson. Eurasian Journal of Educational Research, 16(66), 1-35. https://doi.org/10.14689/ejer.2016.66.18

Lefevre, A. E., Shillcut, S. D., Waters, H. R., Shah, R., Williams, E. K., Black, R. E., ... Wall, S. N. (2013). Economic evaluation of neonatal care packages in a cluster-randomized controlled trial in Sylhet, Bangladesh. Bulletin of the World Health Organization, 91(10), 736-745. https://doi.org/10.2471/BLT.12.117127

Patel, B., Gurmeet, P., Sinalkar, D., Pandya, K., Mahen, A., \& Singh, N. (2016). A study on knowledge and practices of antenatal care among pregnant women attending antenatal clinic at a Tertiary Care Hospital of Pune, Maharashtra. Medical Journal of Dr. D.Y. Patil University, 9(3), 354. https://doi.org/10.4103/0975-2870.182507

Purcaru, D., Preda, A., Popa, D., Moga, M. A., \& Rogozea, L. (2014). Informed consent: How much awareness is there? PLOS ONE, 9(10), 9-14. https://doi.org/10.1371/journal.pone.0110139

Ross, J. J., Ren, J. fang, Land, W., Chandrasekaran, K., \& Mintz, G. S. (1990). Transthoracic high frequency $(7.5 \mathrm{MHz})$ echocardiographic assessment of coronary vascular reserve and its relation to left ventricular mass. Journal of the American College of Cardiology, 16(6), 1393-1397. https://doi.org/10.1016/0735-1097(90)90382-Y

S.Y., K., S.M., L., J.K., J., Y.J., H., M.H., K., J.-Y., S., ... H.M., R. (2018). Prospective observations study protocol to investigate cost-effectiveness of various prenatal test strategies after the introduction of noninvasive prenatal testing. BMC Pregnancy and Childbirth, 18(1), 1-7. https://doi.org/10.1186/s12884-018-1930-y

Sandall, J., Soltani, S., Gates, S., Shennan, A., \& Devane, D. (2016). Midwifeled continuity models versus other models of care for childbearing women (Review). Cochrane Database of Systematic Reviews, 4(10), 46-67. https://doi.org/10.1002/14651858.CD004667.pub5

Singh, S., Doyle, P., Campbell, O. M., Mathew, M., \& Murthy, G. V. S. (2016). Referrals between public sector health institutions for women with obstetric high risk, complications, or emergencies in India - A systematic review. PLOS ONE, 11(8), 1-23. https://doi.org/10.1371/journal.pone.0159793

The Effect of Communicative Activities on EFL Learners ' Motivation : A Case of Students in the Amazon Region of Ecuador Efecto de actividades comunicativas en la motivación de aprendices del inglés : un caso de estudiantes en la región amazónica del Ecua. (2016), 18(2), 39-48.

Vandenberghe, C., Bentein, K., \& Stinglhamber, F. (2004). Affective commitment to the organization, supervisor, and work group: Antecedents and outcomes. Journal of Vocational Behavior, 64(1), 47-71. https://doi.org/10.1016/S0001-8791(03)00029-0

Yeoh, P. L., Hornetz, K., \& Dahlui, M. (2016). Antenatal care utilisation and content between low-risk and high-risk pregnant women. PLOS ONE, 11(3), 1-17. https://doi.org/10.1371/journal.pone.0152167 